\title{
Kirjallisuuden kautta Venäjän pohjoiseen
}

Viime aikoina Suomessa on jälleen virinnyt keskustelua koululaisten kielitaidon kaventumisesta. Ensimmäisen vieraan kielen oppimisen aloitus on aikaistettu alkamaan ensimmäiseltä luokalta, ja vaikka suunnitelmissa kannustettiin valitsemaan "harvinaisempia" pitkiä kieliä kuten saksaa, ranskaa tai venäjää, ensimmäiseksi eli A1-kieleksi valikoituu tavallisimmin englanti. Tosin ainakin Tampereella on erilaisten kieliesittelyjen avulla saatu onnistuneesti moninaistettua valintoja.

Vieraiden kielten opiskelun kaventuminen näkyy yläkouluissa ja lukio-opiskelussa - tilastotietojen mukaan 25 vuotta sitten, vuonna 1996, yläkoulujen oppilaista 43 prosenttia luki valinnaista B2-kieltä. Vuonna 2017 osuus oli reilut 11 prosenttia. Laskussa ovat olleet etenkin saksan ja ranskan lukijoiden määrät, venäjä on ollut "pieni" jo pidempään - vaikkakin juuri yläasteikäisten B2-kielenä sen opiskelu on hiukan jopa noussut 2000-luvulla. Lukiossa kielten opiskelun suosiota ovat vieneet ylioppilaskirjoitusten muutos ja korkeakoulujen pääsykokeiden pistetaulukot, jotka näyttävät ohjaamaan valitsemaan esimerkiksi pitkää matematiikkaa ennemmin kuin lyhyitä kieliä.

Kielitaito on paljon muutakin kuin "teknistä" taitoa sanaston ja kieliopin osaamisineen - kielten opinnoissa avautuu mahdollisuus tutustua muihin kulttuureihin ja kerätä ymmärrystä maailmasta eri tavalla kuin jos olisi aina käännösten varassa. Esimerkiksi ulkomaita koskeviin uutisiin saa lähempää kosketuspintaa, kun pystyy tutustumaan myös alkukielisiin lähteisiin. Omassa tutkimuksessani olen havainnut kirgisialaisten tiedotusvälineiden käyttävän ulkomaanuutisissaan valtaosin venäläisiä, venäjänkielisiä lähteitä, kun toimittajien kielitaito ei taitu laajempaan lähdevalikoimaan. Kirgisialaisen toimittajan kanssa tehdyssä tutkimushaastattelussa haastateltavalle vinkatut suomalaiset Ylen venäjänkieliset uutiset herättivätkin heti kiinnostusta.

Kulttuureihin pääsee tutustumaan lähemmin myös muun muassa kirjallisuuden kautta. Tämän Idäntutkimuksen teemana on Pohjoinen kirjallisuus. Teemanumeron nimessä maantieteellinen ulottuvuus ja kirjallisuuden tutkimuksen näkökulma yhdistyvät lehden historian näkökulmasta uudella tavalla. Maantieteeseen, tilaan ja politiikkaan liittyvistä määritelmistä Idäntutkimuksessa on keskusteltu monesti, muun muassa siitä mitä on "toinen Eurooppa" (Idäntutkimus 3/2002) ja Itämeri (2/2017). Teemanumeroiden aiheena ovat vuosien varrella olleet esimerkiksi Baltia, Karjala, Ukraina ja Mustameri. Pohjoisen teemaa lähimmäs on 
teemanumeroissa aiemmin tullut Arktinen-numero (4/2016), jolloin tarkastelussa olivat muun muassa energiakysymykset ja poliittinen viestintä.

Tässä numerossa katse suuntautuu kirjallisuuteen ja avaa uusia näkökulmia Venäjän pohjoisten alueiden tarkasteluun ja ymmärtämiseen erityisesti alkuperäiskansojen sekä luonnon ja ihmisen suhteen näkökulmasta. Numeron vierailevat toimittajat Tintti Klapuri ja Karina Lukin avaavat teemanumeron kontekstia kolumnissaan. Artikkeleissa Mika Perkiömäki käsittelee Boris Šerginin tuotantoa osana pomorien narratiivista identiteettiä ja Karina Lukin nenetsikirjailija Vasili Ledkovin romaania porojen kollektivisoinnista. Myös Eeva Kuikka tarkastelee nenetsejä käsittelevää kirjallisuutta Anna Nerkagin tuotannon ja hänen pienoisromaanistaan tehdyn elokuvan pohjalta. Arja Rosenholm ja Elena Trubina puolestaan analysoivat "pohjoisen tekstin" kulttuurista käsitettä.

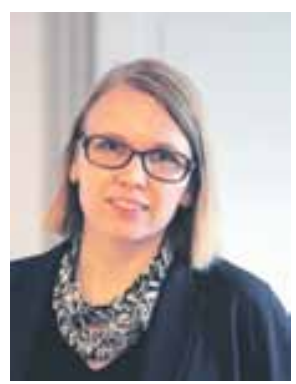

Katja Lehtisari 